\title{
Effect of Drying Methods on Cup Quality of Selected Cultivars of Arabica Coffee (Coffea arabica L.) Grown in South West, Ethiopia
}

\author{
Mikru Tesfa ${ }^{1, *}$, Solomon Abera ${ }^{2}$, Abrar Sualeh $^{3}$ \\ ${ }^{1}$ College of Agriculture, Food and Climate Science, Injibara University, Injibara, Ethiopia \\ ${ }^{2}$ Food Science and Post-harvest Technology, Haramaya University Institute of Technology, Haramaya, Ethiopia \\ ${ }^{3}$ Coffee Processing and Quality Research, Jimma Agricultural Research Center, Jimma, Ethiopia

\section{Email address:} \\ mikrutesfa27@gmail.com (M. Tesfa),aberasol22@gmail.com (S. Abera),mabrarsualeh@yahoo.com (A. Sualeh) \\ ${ }^{*}$ Corresponding author
}

\section{To cite this article:}

Mikru Tesfa, Solomon Abera, Abrar Sualeh. Effect of Drying Methods on Cup Quality of Selected Cultivars of Arabica Coffee (Coffea arabica L.) Grown in South West, Ethiopia. Agriculture, Forestry and Fisheries. Vol. 10, No. 2, 2021, pp. 52-60.

doi: $10.11648 /$ j.aff.20211002.13

Received: November 19, 2020; Accepted: December 14, 2020; Published: March 10, 2021

\begin{abstract}
Coffee Arabica is an essential commodity to the livelihood of millions of Ethiopians and its quality had critical importance to the coffee industry. A study was conducted to evaluate coffee quality attributes of nine newly released coffee cultivars subjected to open sun (direct sun light) and lath house-drying methods. The experiment was designed in complete randomized design factorial with two factors (cultivars and drying methods). Coffee cultivars were (Gawe, Dessu, 744, 7440, 74148, Gesha, Merdacheriko, Wushwush and Catimor J-19) prepared using wet (washed) processing method during harvesting of 2017/18 cropping season, which were collected from different altitude of south west, Ethiopia. Cup quality was evaluated by a team of certified panelists at Jimma agricultural research center coffee processing and quality analysis laboratory. The highest value in most cup quality attributes were record in cultivars of Gesha and 74148. Similarly, cultivars of 744 and 7440 were highest in all cup quality parameters. Net lath house drying method was better in all cup quality attributes. Effect of drying method was significant difference $(\mathrm{P} \leq 0.05)$ on cup quality parameters such as aromatic quality, astringency, bitterness, body and flavor. The interaction effect of cultivar and drying method shown significant difference $(\mathrm{P} \leq 0.05)$ on cup quality parameter except aromatic intensity. In the future to improve and maintain coffee quality different drying method should be practiced.
\end{abstract}

Keywords: Coffee Arabica, Coffee Quality, Coffee Cultivar, Drying Method

\section{Introduction}

The coffee bean is obtained from the fruit of the coffee plant, a small evergreen shrub belonging to the genus Coffea, family Rubiaceae. Although the genus Coffea is diverse and reported to comprise about 103 species [14], only two species namely Arabica (Coffea arabica L.) and Robusta (Coffea canephora) are under commercial cultivation $[5,25,30]$ Arabica coffee accounts for about $70 \%$ of the world coffee production and known for the preparation of high quality beverage [5]. Ethiopia is the original home of Coffea arabica L, and thus, possesses the largest diversity in coffee genetic resources [20, 27]. Coffee contributes the Lion's share in the national economy being the leading source of foreign exchange earnings [39]. It is an essential commodity to the livelihood of millions of Ethiopians. The largest volume of coffee is grown in the two regions of Oromia and the Southern Nations, Nationalities and Peoples Region. Only five to eight percent of coffee production is grown on modern plantations, which are owned by private investors or by the government [38] Smallholder farmers grow the rest, and about half of that production is in backyards or gardens. In both cases (modern plantations as well as smallholder production), coffee is generally grown under shade [7].

Beverage quality often referred to as drinking quality or liquor quality is an important attribute of coffee $[28,3]$ and acts as yardstick for price determination. The term "green coffee bean" 
refers to un-roasted mature or immature coffee beans. These have been processed by wet or dry method for removing the outer pulp and mucilage, and have an intact wax layer on the outer surface. Coffee beverage quality is based on the characterization of a large number of factors including taste and aroma. A thousand of compounds, appearing during roasting are involved in coffee beverage quality. These compounds rise from a smaller number of biochemical compounds present in green beans. Beverage quality assessment as a sufficiently reliable for use as a basis of selection in quality improvement programs. The criteria commonly used to evaluate the quality of coffee beans include bean size, color, shape, roast potential, processing method, storage period, flavor or cup quality, and the presence of defects [17, 37].

Coffee drying is one of the most important steps in quality coffee production so coffee cherries are dried immediately after harvest to reduce moisture content in optimum level (10$11.5 \%$ ), which allows safe storage over an extended period. Drying under open sun (direct sun light) using the solar radiations for food preservation are practiced since ancient times [35]. The use of direct sun drying process of coffee in terraces is still very common among the coffee producers [13]. However, it requires high labor; it is a time requiring operation, dependent on the climatic conditions as well as leads to contamination by foreign materials. To overcome these short comings, various drying techniques have been proposed in recent time to maintain quality of products. Therefore, the objectives of this study were to evaluate cup quality of coffee as affected by differences cultivars and drying methods.

The objectives of the present study were:

To evaluate the effect of two drying methods (open sun and Net Lath house) on cup quality of the selected coffee cultivars grown in south west, Ethiopia

\section{Coffee Cup Quality}

The most important parameter in the appreciation of coffee quality is the organoleptic quality of the cup which is mainly due to the volatile substances present as well as sensory analysis referred to as cup quality. The cup quality is determined based on the level of mainly acidity, body and flavour of the brew [46]. Production and supply of coffee with excellent quality appear more crucial than ever before for coffee exporting countries. Quality coffee is a product that has desirable characteristics such as clean raw and roasted appearance, attractive aroma and good cup taste [9].

Cup coffee quality as the ability of a product to satisfy consumer's expectation by way of good sensory characteristics in the absence of off-flavors and different defects [24]. The definition of coffee quality varies along the production-to-consumer chain. At the farmer level, coffee quality is a combination of production level, price and easiness of culture; at the exporter or importer level, coffee quality is linked to bean size, lack of defects and regularity of provision, tonnage available, physical characteristics and price; at the roaster level, coffee quality depends on moisture content, stability of the characteristics, origin, price, biochemical compounds and organoleptic quality. At the consumer level: coffee quality deals with price, taste and flavor, effects on health and alertness, geographical origin, environmental and sociological aspects (organic coffee, fair trade, etc [24].

The criteria for green coffee sale and purchase includes the geographic origin (country, region, state, plantation); the botanic origin (species, variety); the crop year; the moisture content; the total defect and foreign matter; the content of insect damaged beans; the bulk density and the bean size. Coffee quality is conformance with requirements or fitness for use in which the parties involved in the industry (customer, processor, supplier, etc) should agree on the requirements and the requirements should be clear to all stake holders involved in the process [31]. On the other hand, Coffee quality control and auction center was established with a key objective of maintaining coffee quality control, which in turn facilitates the coffee marketing system to be standard based, and for the betterment /proper functioning of the long coffee supply chain of Ethiopia [15]. Coffee quality inspection is universally applicable in both coffee producing and consuming countries according to the quality control system of the respective countries [12].

Coffee quality refers to beans flavor in fragrance, aroma, flavor, sweetness, acidity or overall taste felt by consumer after drink as well as physical characteristics such as length, width, thickness or weights, shape and color of coffee beans [19].

Coffee has only one value to give the consumer pleasure and satisfaction through flavor, aroma and desirable physiological and psychological effects [41]. Therefore, coffee quality, especially liquor or cup quality, determines both the relative price and usefulness of a given quantity of coffee [3]. Cup quality, often referred to as drinking quality or liquor quality, is an important attribute of coffee $[3,28]$ and acts as yardstick for price determination [6].

Coffee bean drying: Drying is considered an important step in quality coffee production, since moisture levels higher than $12 \%$ can promote microbial growth and mycotoxin formation [18, 32, 40]. The main propose of drying is to maintain the moisture content of the parchment optimum for storage. Freshly pulped coffee has a moisture content of about $55 \%$ and that has to be reduced by drying to $11 \%$. This is the ideal level of moisture content required for proper storage, hulling and roasting. In most of the developing countries, open sun drying is predominantly used and mainly by the producers' organizations/cooperatives, and the coffee is spread on the wire mesh tables for normally about two weeks in sunny days, until fully dry. Few commercial companies use mechanical drying method [29]. If drying is carried out too rapidly, 'case hardening' may occur which is common in the drying of many grains. The surface is over dried and shrinks irreversibly to prevent easy movement of moisture from within the bean in an outward direction. Field evidences have shown that when drying is done too rapidly under excessively warm temperatures, the valuable cup flavor is largely lost from coffee that otherwise would have been considered excellent [36]. [26] 
Reported coffee beans may require more days to dry depending on the methods of drying and the density at which the beans are dried. [23] also confirmed that mesh tables characteristically wilt with the result that layer thickness, and consequently drying rates, are not uniform. For a given thickness layer, the length of the drying process depends mainly on weather conditions and degree of moisture content and size of the cherries [16]. The digital method relied on a digital coffee moisture meter (tester), when correctly calibrated; it is the best method to determine moisture content of coffee rather than subjective method. Poor drying operations, such as mixed drying and undesirable layer thickness of coffee upon drying and heaping of coffee before drying favor the development of fungus and bacteria that inevitably cause quality deterioration. For instance, the covering period during drying and depth of parchment or cherry layers affects the total time require to dry to an optimum moisture level, the extended drying time observed when drying depth and the duration of covering period increased [8]. Parchment coffee dried at the highest drying depth $(5 \mathrm{~cm})$ gave the lowest value of cup quality, while drying depth of 3 and $4 \mathrm{~cm}$ gave better values of cup quality [9]. Drying was greatly affected by coffee types, processing and drying methods. Coffee drying on raised beds covered with mesh wire or bamboo mat produced best quality coffee by scoring the highest raw and cup quality value of coffee bean. Similarly, [6] reported that, coffees drying by using raised bed with mesh wire, wooden and bamboo mats have better quality. However, drying coffee directly on soil or dirty surfaces can lead to dirty or earthy flavors in the finished coffee [16]. Also, coffee dried on bricks affect raw quality of the bean due less air movement that favor mold development and black (foxy) bean formation. Hence, inappropriate drying materials and place increase the black (foxy) bean formation that maximizes the degree of defect counts and affects the odor and color of the coffee that finally affects the raw quality of green beans. Drying together different day harvested cherries would affects the final quality of green coffee beans [22, 33].

\section{Materials and Methods}

\subsection{Description of Study Area}

The study was conducted at Jimma Agricultural Research Center (JARC) and the coffee samples were obtained from Jimma (Melko), Teppi Agricultural Research Center and Gera sub center of JARC from harvests of 2017/2018 cropping season collected from coffee trees of 8 - 10 years age. Jimma Agricultural Research Center is located in Jimma zone, Oromia National Regional State, $358 \mathrm{~km}$ away southwest of the capital, Addis Ababa. The centre (Melko) is found at a distance of $10 \mathrm{~km}$ west of Jimma city and located at $7^{\circ} 40^{\prime} 37^{\prime \prime} \mathrm{N}$ and $36^{\circ} 49^{\prime} 47^{\prime \prime} \mathrm{E}$ and at an altitude of $1753 \mathrm{~m}$ above sea level. The average minimum and maximum temperatures are 11.9 and $26.2^{\circ} \mathrm{C}$, respectively. The area receives an average annual rainfall of $1532 \mathrm{~mm}$. Teppi National Spice Research Center (TNSRC) is located in Yeki district, Sheka Zone of Southern Nations, Nationalities and Peoples' Regional State, which is $600 \mathrm{~km}$ away southwest of the capital, Addis Ababa. It is found at $35^{\circ} 08^{\prime} 28^{\prime \prime} \mathrm{E}$ longitude and $7^{\circ} 08^{\prime} 54^{\prime \prime} \mathrm{N}$ latitude and at an altitude of $1200 \mathrm{~m}$ above sea level.

The average minimum and maximum temperatures are 15 and $30^{\circ} \mathrm{C}$, respectively. It receives an average annual rainfall of $1630 \mathrm{~mm}$ [34]. The relative humidity of the site reaches 80 to $90 \%$ and the soil type is Nitosoil dominated by a loam texture [21]. Gera agricultural research sub center of the Jimma agricultural research center is located at latitudinal gradient of $7^{\circ} 70^{\prime \prime} \mathrm{N}$ and longitudinal gradient $36^{\circ} 35^{\prime \prime} \mathrm{E}$ with an altitude of $1940 \mathrm{~m}$ above sea level. The mean annual rainfall of the area is $1878 \mathrm{~mm}$ with an average maximum and minimum air temperatures of 24.4 and $10.5^{\circ} \mathrm{C}$, respectively.

\subsection{Experimental Materials and Description}

Samples of nine coffees Arabica (Coffea arabica L.) cultivars adapted for mid land (1500-1750 meter above sea level), high land (above 1750) and low land (500-1500) altitudes were collected of the 2017/18 harvesting season at Jimma (Melko), Gera and Teppi growing areas. The coffee prepared samples were to represent each agro ecological zone. Harvesting was conducted in the period between mid of October and December 2017. Eight-kilo grams red ripe coffee cherries were harvested by hand picking from each selected coffee cultivars from the indicated areas and prepared by wet processing method.

\subsection{Experimental Design}

The experiment was arranged with two factors, coffee cultivars and coffee bean drying methods. The first factor consisted of levels with nine cultivars selected to represent different growing altitudes. The cultivars were Gesha, Catimor J19, Dessu, and 744,7440,74148, Gawe, Merdacheriko and Wushwush. The second factor drying method consisted of two levels open sun drying and net lath house drying. Black net lath house transmits $48-50 \%$ UV light, measured by light meter (Extch, Model EA30, and Taiwan). From each coffee cultivar, samples were equally divided into each drying method and finally dried. Each treatment combination was done in triplicate and the experiment laid out in a Completely Randomized Design (CRD).

Table 1. Treatment combinations.

\begin{tabular}{llll}
\hline \multirow{2}{*}{ S/N } & \multirow{2}{*}{ Coffee cultivars } & \multicolumn{2}{l}{ Drying methods } \\
\cline { 3 - 4 } & & OS & LH \\
\hline 1 & $\mathrm{~V}_{1}$ & $\mathrm{~V}_{1} \mathrm{O}_{\mathrm{S}}$ & $\mathrm{V}_{1} \mathrm{~L}_{\mathrm{H}}$ \\
2 & $\mathrm{~V}_{2}$ & $\mathrm{~V}_{2} \mathrm{O}_{\mathrm{S}}$ & $\mathrm{V}_{2} \mathrm{~L}_{\mathrm{H}}$ \\
3 & $\mathrm{~V}_{3}$ & $\mathrm{~V}_{3} \mathrm{O}_{\mathrm{S}}$ & $\mathrm{V}_{3} \mathrm{~L}_{\mathrm{H}}$ \\
4 & $\mathrm{~V}_{4}$ & $\mathrm{~V}_{4} \mathrm{O}_{\mathrm{S}}$ & $\mathrm{V}_{4} \mathrm{~L}_{\mathrm{H}}$ \\
5 & $\mathrm{~V}_{5}$ & $\mathrm{~V}_{5} \mathrm{O}_{\mathrm{S}}$ & $\mathrm{V}_{5} \mathrm{~L}_{\mathrm{H}}$ \\
6 & $\mathrm{~V}_{6}$ & $\mathrm{~V}_{6} \mathrm{O}_{\mathrm{S}}$ & $\mathrm{V}_{6} \mathrm{~L}_{\mathrm{H}}$ \\
7 & $\mathrm{~V}_{7}$ & $\mathrm{~V}_{7} \mathrm{O}_{\mathrm{S}}$ & $\mathrm{V}_{7} \mathrm{~L}_{\mathrm{H}}$ \\
8 & $\mathrm{~V}_{8}$ & $\mathrm{~V}_{8} \mathrm{O}_{\mathrm{S}}$ & $\mathrm{V}_{8} \mathrm{~L}_{\mathrm{H}}$ \\
9 & $\mathrm{~V}_{9}$ & $\mathrm{~V}_{9} \mathrm{O}_{\mathrm{S}}$ & $\mathrm{V}_{9} \mathrm{~L}_{\mathrm{H}}$ \\
\hline
\end{tabular}

$\mathrm{OS}=$ Open sun drying, $\mathrm{LH}=$ Lath house drying; $\mathrm{V} 1=$ Gawe, $\mathrm{V} 2=\mathrm{Dessu}$, $\mathrm{V} 3=744, \mathrm{~V} 4=74148, \mathrm{~V} 5=7440$ and $\mathrm{V} 6=\mathrm{Gesha}, \mathrm{V} 7=\mathrm{CJ}-19, \mathrm{~V} 8=$ Wushwush, V9= Merdacheriko 


\subsection{Coffee Bean (Sample) Preparation}

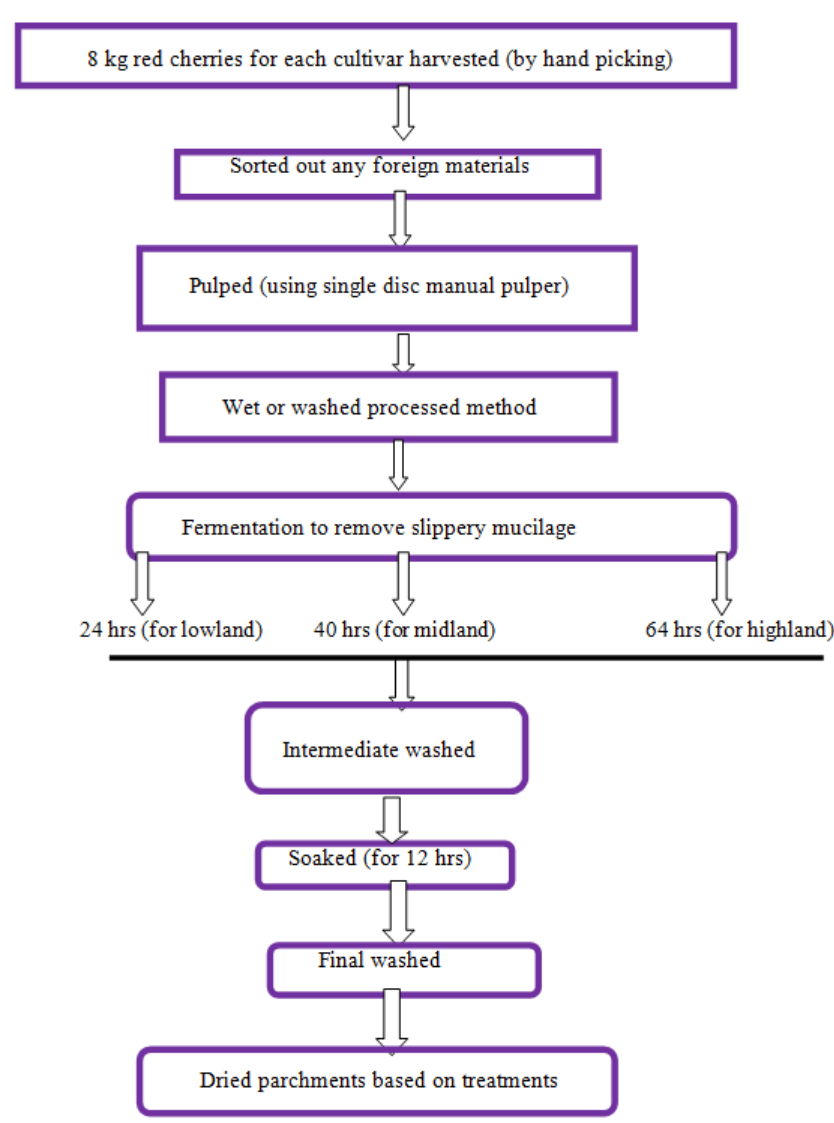

Figure 1. Sample (Coffee green bean) preparation.

\subsection{Data Collection, Brew Preparation and Cup Evaluation}

Roasting and grinding: The roasting process causes the coffee beans to swell and increase their size by over $50 \%$, while at the same time greatly reducing their weight [22]. Temperature and time are two critical things that have to keep in mind during roasting to obtain better quality coffee. The roaster machine with six cylinders (Probat Welke, Von Gimborn Gmbhan Co. KJ, Germany) was used for roasting. One-hundred gram of dried green beans from each sample was weighed with a sensitive balance.

The roaster machine was first heated to $200^{\circ} \mathrm{C}$ and hundred gram beans per sample was put in to roasting cylinder and roasted for an average of 6-8 minutes to a medium roast under roasting temperature of $200^{\circ} \mathrm{C}$ [1]. The medium roasted beans were then, tipped out into a cooling tray and allowed immediately to cool down for by blowing cold air over the cooling plate. The roasted and cooled beans were blown to remove the loose silver skin (chaff). About half of hundred gram medium roasted beans of each sample was ground to medium size using electrical coffee grinder (Mahlkonig, Germany) adjusted to $1.5 \mathrm{~mm}$ diameter of sieve size. During grinding, the grinder was cleaned well after each sample was ground. In order to avoid the loss of aroma, roasted coffee should be ground immediately before being made for brewing purpose as aroma is quickly lost from ground coffee [22].
According to Jimma coffee processing and quality analysis laboratory manual, three up to five clean standard porcelain cups with $180 \mathrm{ml}$ capacity (Schonwald, Germany) per sample were prepared. Soon after grinding, 8 gram of coffee powder was put into each cup per sample similar to CLU [12]. Fresh boiled $\left(93^{\circ} \mathrm{C}\right)$ water was poured into the cup with prepared powder coffee up to about half of the cup. Then, the content of the cup was stirred in order to ensure the homogeneity of the mixture of coffee powder with boiled water in a cup. Before filling cup with fresh boiled water, the volatile aromatic quality and intensity parameters were evaluated by tasting and sniffing, respectively with team of panelists. Then the cup were filled with water to the size $(180 \mathrm{ml})$ and left to settle for about 3 minutes. Then, the floater was skimmed and the brew was ready for panelists within 8 minutes or beverage cooled to around $60^{\circ} \mathrm{C}$ (drinkable temp.) for cup coffee quality evaluation [2]. After the preparation of coded brew samples team of three experienced and internationally certified cuppers of Jimma Agricultural Research Center (JARC) were evaluated the following cup quality attributes. Each panelist gave his own judgment value for each coded brewed coffee sample. Finally, the average results of all panelists were used for data analysis. Sensory evaluation was done for all cup quality parameters including, bitterness, astringency, acidity, body, flavor, aromatic intensity and aromatic quality and over all cup quality.

Aromatic quality: It indicates the perception by the panelist of the character of coffee in the mouth. It was evaluated by scoring out of $5 \%$ as unacceptable (0), bad (1), regular (2), good (3), very good (4) and excellent (5).

Aromatic intensity: It is magnitude of aroma as evaluated by scoring out of $5 \%$ as, nil (0), very light (1), light (2), medium (3), strong (4) and very strong (5) ranged from 0 to 5 .

Bitterness and astringency: Both parameters were evaluated out of $5 \%$ using scales ranged from 0 to 5 . As very strong (0), strong (1), medium (2), light (3), very light (4) and nil (5).

Acidity: It is a primary coffee taste sensation created from the combined action of acids and Sugar within the coffee bean. It is also the sense of coffee on the tongue in order to identify strength of the brew. It was scored out of $10 \%$ as nil (0), lacking (2), light (4), medium (6), medium pointed (8) and pointed (10).

Body: It is the feeling that the coffee creates in one's mouth. The viscosity, heaviness, thickness, or richness is perceived on the tongue. Thus, it indicates the texture and sensation of coffee in the mouth, which was evaluated by scoring out of $10 \%$ as nil (0), very light (2), light (4), medium (6), medium full (8) and full (10).

Flavor: It is the overall perception of the coffee in a mouth. It is the combination of body, acidity and over all taste of the brew. It was evaluated by scoring out of $10 \%$ as nil (0), bad (1), fair (4), average (6), good (8) and very good (10).

Overall Cup Quality: It was scored out of $10 \%$ using the following scales, unacceptable (0), bad (2), regular (4), good (6), very good (8) and excellent (10). 


\subsection{Statistical Data Analysis}

Analysis of variance (ANOVA) was computed for each cup quality parameter data using General Linear Model (GLM) of SAS procedure version 9.0. In order to identify the variability among the treatments in CRD factorial design. For characters having significant mean differences, the difference between treatment means was compared using least significant difference (LSD) at $5 \%$ level of significance.

\section{Results and Discussions}

\subsection{Effect of Cultivars and Drying Methods on Cup Coffee Quality Attributes}

Cup quality attributes data such as aromatic intensity, aromatic quality, acidity, astringency, bitterness, body, flavor and overall as influenced by cultivars and drying methods are shown in Table 2.

Aromatic intensity results evaluated out of scale of $5 \%$ ranged from 3.25 of cultivar Gawe to 3.83 of cultivar CJ-19 and showed significant $(\mathrm{P} \leq 0.05)$ difference. Most cultivars exhibited values between above indicated values no showed significant $(\mathrm{P} \geq 0.05)$ difference from each other, while the effect of drying methods showed no significant difference on aromatic intensity.
Aromatic quality values of brewed coffee ranged from 3.42 and 4.08 for cultivar Gesha and Merdacheriko, respectively, out of a maximum scale of $5 \%$. Most cultivars had values above $3.66 \%$ with no statistical difference. Drying methods showed significant $(\mathrm{P} \leq 0.05)$ difference having values of 3.79 and 3.57 for samples dried in lath house and open sun, respectively.

The result of acidity of brewed coffee cultivars ranged from 6.91 of cultivar CJ-19 to 7.83 of cultivar 74148 out of a maximum scale of $10 \%$ points. All values showed no significant difference except the lowest $6.91 \%$. Drying method exhibited no significant $(\mathrm{P} \geq 0.05)$ difference on acidity with values of 7.48 for samples dried in lath house and 7.40 for samples dried in open sun.

Astringency data of the brew of different coffee cultivars did not show significant difference $(\mathrm{P} \geq 0.05)$ attributed to cultivars. With values numerically ranging from 3.75 to 4.16 in maximum scale of $5 \%$ points. On the other hand, the effect of drying methods showed significant $(\mathrm{P}<0.05)$ difference on astringency with recorded values of $\overline{4} .18$ and 3.68 for samples dried in lath house and open sun, respectively.

The data of bitterness of brewed coffee evaluated out of a maximum scale of $5 \%$ points ranged from 3.33 of cultivar CJ-19 to 4.08 of cultivar Gesha. Most cultivars exhibited statistically the same values.

Table 2. The effect of cultivars and drying methods on cup quality attributes

\begin{tabular}{|c|c|c|c|c|c|c|c|c|}
\hline \multirow[b]{2}{*}{ Cultivars } & \multicolumn{8}{|c|}{ Cup quality parameters } \\
\hline & AI & AQ & AC & $\mathbf{A S}$ & BI & BO & FL & OL \\
\hline Gawe & $3.25^{\mathrm{c}}$ & $3.75^{\mathrm{ab}}$ & $7.42^{\mathrm{ab}}$ & $3.91^{\mathrm{a}}$ & $3.50^{\mathrm{bc}}$ & $7.66^{\mathrm{ab}}$ & $7.16^{\mathrm{ab}}$ & $7.41^{\mathrm{ab}}$ \\
\hline Dessu & $3.33^{\mathrm{bc}}$ & $3.75^{\mathrm{ab}}$ & $7.66^{\mathrm{a}}$ & $3.91^{\mathrm{a}}$ & $4.00^{\mathrm{ab}}$ & $7.50^{\mathrm{ab}}$ & $6.58^{\mathrm{b}}$ & $7.58^{\mathrm{a}}$ \\
\hline 744 & $3.50^{\mathrm{abc}}$ & $3.75^{\mathrm{ab}}$ & $7.42^{\mathrm{ab}}$ & $3.83^{\mathrm{a}}$ & $3.83^{\mathrm{abc}}$ & $7.41^{\mathrm{ab}}$ & $7.00^{\mathrm{ab}}$ & $7.41^{\mathrm{ab}}$ \\
\hline 74148 & $3.66^{\mathrm{ab}}$ & $3.58^{\mathrm{b}}$ & $7.83^{\mathrm{a}}$ & $4.08^{\mathrm{a}}$ & $3.75^{\mathrm{abc}}$ & $7.75^{\mathrm{a}}$ & $7.41^{\mathrm{a}}$ & $7.75^{\mathrm{a}}$ \\
\hline 7440 & $3.58^{\mathrm{abc}}$ & $3.66^{\mathrm{ab}}$ & $7.50^{\mathrm{a}}$ & $3.75^{\mathrm{a}}$ & $3.75^{\mathrm{abc}}$ & $7.66^{\mathrm{ab}}$ & $7.33^{\mathrm{a}}$ & $7.33^{\mathrm{ab}}$ \\
\hline Gesha & $3.50^{\mathrm{abc}}$ & $3.42^{\mathrm{c}}$ & $7.50^{\mathrm{a}}$ & $3.91^{\mathrm{a}}$ & $4.08^{\mathrm{a}}$ & $7.33^{\mathrm{ab}}$ & $7.41^{\mathrm{a}}$ & $7.33^{\mathrm{ab}}$ \\
\hline CJ-19 & $3.83^{\mathrm{a}}$ & $3.66^{\mathrm{ab}}$ & $6.91^{\mathrm{b}}$ & $3.83^{\mathrm{a}}$ & $3.33^{\mathrm{c}}$ & $7.50^{\mathrm{ab}}$ & $6.91^{\mathrm{ab}}$ & $6.91^{\mathrm{b}}$ \\
\hline Wushwush & $3.58^{\mathrm{abc}}$ & $3.50^{\mathrm{b}}$ & $7.42^{\mathrm{ab}}$ & $4.16^{\mathrm{a}}$ & $3.66^{\mathrm{abc}}$ & $7.16^{\mathrm{b}}$ & $7.41^{\mathrm{a}}$ & $7.25^{\mathrm{ab}}$ \\
\hline Merdacheriko & $3.39^{\mathrm{bc}}$ & $4.08^{\mathrm{a}}$ & $7.33^{\mathrm{ab}}$ & $4.00^{\mathrm{a}}$ & $3.58^{\mathrm{abc}}$ & $7.50^{\mathrm{ab}}$ & $7.08^{\mathrm{ab}}$ & $7.33^{\mathrm{ab}}$ \\
\hline CV $(\%)$ & 9.8 & 7.3 & 5.3 & 6.9 & 7.10 & 3.8 & 5.3 & 5.6 \\
\hline $\operatorname{LSD}(0.05)$ & 0.4 & 0.43 & 0.55 & 0.46 & 0.52 & 0.51 & 0.58 & 0.57 \\
\hline \multicolumn{9}{|c|}{ Drying methods } \\
\hline Lath house & $3.54^{\mathrm{a}}$ & $3.79^{\mathrm{a}}$ & $7.48^{\mathrm{a}}$ & $4.18^{\mathrm{a}}$ & $4.00^{\mathrm{a}}$ & $7.74^{\mathrm{a}}$ & $7.25^{\mathrm{a}}$ & $7.38^{\mathrm{a}}$ \\
\hline Open sun & $3.49^{\mathrm{a}}$ & $3.57^{\mathrm{b}}$ & $7.40^{\mathrm{a}}$ & $3.68^{\mathrm{b}}$ & $3.44^{\mathrm{b}}$ & $7.25^{\mathrm{b}}$ & $7.03^{\mathrm{a}}$ & $7.35^{\mathrm{a}}$ \\
\hline CV (\%) & 8.07 & 9.32 & 6.78 & 7.6 & 8.26 & 5.02 & 7.42 & 6.93 \\
\hline $\operatorname{LSD}(0.05)$ & 0.19 & 0.2 & 0.27 & 0.16 & 0.2 & 0.2 & 0.28 & 0.27 \\
\hline
\end{tabular}

Means having the same letter in columns are not significant difference $(\mathrm{P}>0.05) ; \mathrm{AI}=$ aromatic intensity, $\mathrm{AQ}=$ aromatic quality, $\mathrm{AC}=$ acidity, $\mathrm{AS}=$ astringency, $\mathrm{BI}=$ bitterness, $\mathrm{BO}=$ body, $\mathrm{FL}=$ flavor, $\mathrm{OL}=$ overall; $\mathrm{LH}=$ lath house, $\mathrm{OS}=$ open sun; $\mathrm{CV}=$ coefficient variation, $\mathrm{LSD}=$ least significant difference

The effect of drying method showed significant $(\mathrm{P} \leq 0.05)$ difference on bitterness with the values of 4.00 for samples dried in lath house and 3.44 for those dried in open sun.

The majority data of body of brewed of the coffee cultivars exhibited no significant $(\mathrm{P} \geq 0.05)$ differences in recorded scores except for cultivar Wushwush which scored 7.16 which is statistically lower than the 7.75 of the highest record. Out of a maximum scale of $10 \%$ points values varied between 7.16 of Wushwush cultivar and 7.75 of cultivar 74148. Drying method also showed significant difference ( $\mathrm{P} \leq$ 0.05 ) on body attributes with values of 7.74 and 7.25 out of a scale $10 \%$ point scored by samples dried in lath house and open sun, respectively.

Regarding the results of flavor of the brew of different coffee cultivars significant differences were not $(\mathrm{P} \geq 0.05)$ observed among the majority of the values. Out of a maximum scale of $10 \%$ points values ranged from 6.58 of cultivar Dessu to 7.41 of cultivars 74148 , Gesha and Wushwush. Drying method showed no significant difference $(\mathrm{P} \geq 0.05)$ on flavor.

Data of overall cup quality of different cultivars ranged from 6.91 of cultivar CJ-19 to 7.75 of cultivar 74148 out of a maximum scale of $10 \%$ points showing significant differences $(P \geq 0.05)$ among them. However, most cultivars 
having above $6.91 \%$ values no showed significant difference $(\mathrm{P} \geq 0.05)$. The effect of drying method on overall quality attribute no showed significant difference $(\mathrm{P} \geq 0.05)$ with their recorded values.

\subsection{Interaction Effect of Cultivars and Drying Methods on Cup Quality Attributes}

Data of cup quality attributes of different coffee cultivars considered in the study influenced by interaction effect of cultivars and drying methods presented in Table 3.

Aromatic intensity data evaluated out of a maximum of five points ranged from $3.20 \%$ of the Merdacheriko cultivar to $3.83 \%$ of cultivar CJ-19 for lath house dried samples, the two having significant $(\mathrm{P} \leq 0.05)$ difference between them.

The majority of the cultivars exhibited values between the above indicated two values with no significant difference ( $\mathrm{P} \geq 0.05)$ among each other. All the values indicated strong aromatic intensity having scores between 3 and 4 . In case of sun-dried samples, the values ranged from 3.12 of Gawe and Dessu cultivars to 3.83 of cultivar 74148 in the same scale. Except the 3.12 score the rest are not significantly different $(\mathrm{P} \geq 0.05)$ from each other. Coffee dried on bricks floor in contact with soils become dirty and blotchy resulting into dull aroma and earthy flavor in coffee beverage. Again, the values remaining above three in a scale of five showed high intensity level. The drying method showed no significant effect $(\mathrm{P} \geq 0.05)$ on aromatic intensity attributed to the two drying methods of the coffee beans.

The aromatic quality of the brewed coffee exhibited values ranging from 3.66 of cultivar Dessu to 4.12 of cultivar Gawe out of a maximum scale of 5 points, for lath house dried coffee beans. Significant $(\mathrm{P} \leq 0.05)$ differences were observed among some of the values. Although, the majority of them are not significantly $(\mathrm{P} \geq 0.05)$ different from each other. The values were greater than 3.5 in a scale of 5 points exhibiting highly appreciated aromatic quality. Similarly, the values for sundried coffee beans are shown in Table 3. The highest value (4.50) belonged to cultivar Merdacheriko whereas the lowest (3.12) was of cultivar Gesha. All the values remained above three in a scale of 5 points indicating that the scores represented acceptable level of aromatic quality. Mean performance variation for cup quality character indicating the presence of great variability among Arabica coffee genotypes.

The astringency scores of the brewed coffee of different cultivars subjected to the two drying methods are included in Table 3. Values for samples dried in lath house ranged from 3.83 of cultivar CJ-19 to 4.50 of cultivar 74148 , all but one values being greater than 4 in scale of 5 points. The significant differences were observed only between the highest and the lowest values, the rest being statistically the same $(P \geq 0.05)$. On the other hand, the values for same attributes of sun-dried samples were, all but one, less than 4 in scale of 5 points. The lowest (3.33) of cultivar 7440 whereas the highest (4.12) was of Wushwush cultivar.

Bitterness scores for lath house dried samples also showed significant differences $(\mathrm{P} \leq 0.05)$ among the cultivars, the highest (4.33) observed for cultivars Dessu and 74148 whereas the lowest (3.33) was recorded for CJ-19. Still the majority values are 4 and above in a scale of 5 . All but one sun-dried sample received less scores than the corresponding variety dried in lath house, the majority of them being less than 4 point. The sun-dried samples are found to be less bitter than lath house dried ones.

The acidity scores of lath house dried samples varied from 7.00 (highest medium pointed) of cultivar CJ-19 up to 8.33 (highest moderately pointed) of cultivar 74148 in scale of 10 points in Table 3, all showing significant $(\mathrm{P} \leq 0.05)$ differences among them. However, all values exhibited acceptable level of acidity with score of well above the midpoint of the scale. High acidity gives better quality and more intense aroma to the beverage [11].

Similar pattern was observed in case of sun-dried coffees with values ranging from 6.83 (least medium pointed) of cultivar CJ-19 to good pointed (7.83) of cultivars Dessu and Gesha. These values had significant $(\mathrm{P} \leq 0.05)$ differences among them. Generally, the values of open sun dried samples appeared to have scores of acceptable acidity levels similar to those dried in lath house. Cultivar CJ-19 exhibited the lowest acidity scores in both lath house and open sun dried samples. A variation in acidity among coffee genotypes collected from the different parts of Ethiopia [41].

Cup quality attributes such as body, flavor and overall quality of the different cultivars considered in the study also presented in Table 2. The points given to the body of the brew of the lath house dried coffee, in scale of 10 ranged from the medium (7.16) of Wushwush cultivar to the medium full (8.50) of cultivar 74148. Many of the values exhibited significant $(\mathrm{P} \leq 0.05)$ differences. Likewise, the values of same attributes for open sun dried samples varied from the lowest (7.00) of cultivar 74148 to the medium (7.66) of cultivar 7440. These values for each cultivar are lower than those of most of the corresponding cultivars of the lath house dried samples except those of cultivars 7440, Gesha and Wushwush. Statistical differences were also noted among some of these values. There was variation in their body among genotypes of Coffee Arabica [41]. Acidity and body are reliable and suitable quality attribute that can be used as selection criteria for the genetic improvement of coffee quality [4].

The scores for flavor of the brewed coffee for samples dried in the lath house were between 7.83 (good) of cultivar 7440 and 6.33 (average) of cultivar Dessu, with significant differences among some. For samples dried in open sun the values ranged from 6.66 (lowest) of cultivars Gawe and 744 to the maximum (7.66) belonging to variety Gesha. Some of the values again exhibited significant $(\mathrm{P} \leq 0.05)$ differences among them. Improper drying practices are the root cause of many flavor taints in coffee [10]. Most of the cultivars had lower points for the open sun dried samples. Drying process more damaging action on the formation of precursors of the sensory quality of coffee occurs when high temperatures are used at the time of low water content in the grains [33].

The scores for the overall quality attribute of lath house 
dried samples were between 7.00 (good) of Gesha and CJ-19 cultivars and 8.33 (very good) of cultivar 74148. Significant $(\mathrm{P} \leq 0.05)$ differences were noted between the highest $(8.33)$ and the majority of the remaining points that did not exhibit statistical difference among themselves. Similar trend were observed among those values of the samples dried in open sun varying between 6.83 of cultivar CJ-19 and 7.83 of cultivar Dessu. All the above indicated value were greater than 6 in a scale of 10 points showing the evaluated attributes received positive acceptance levels.

Drying method and cultivar showed no significant difference $(\mathrm{P} \geq 0.05)$ on overall quality of coffee but had significant difference $(\mathrm{P} \leq 0.05)$ in flavor of studied cultivars of coffee. The presence of large inherent difference among genotypes for cup quality attributes.

Table 3. Interaction effect of drying method and cultivars of coffee on organoleptic quality attributes.

\begin{tabular}{|c|c|c|c|c|c|c|c|c|c|}
\hline \multirow{2}{*}{ Cultivar } & \multirow{2}{*}{ DM } & \multicolumn{8}{|c|}{ Organoleptic coffee quality } \\
\hline & & $\mathbf{A I}$ & AQ & $\mathbf{A C}$ & AS & BI & BO & FL & OL \\
\hline \multirow{2}{*}{ Gawe } & LH & $3.33^{\mathrm{ab}}$ & $4.12^{\mathrm{ab}}$ & $7.83^{\mathrm{ab}}$ & $4.12^{\text {abcde }}$ & $3.83^{\text {bcd }}$ & $7.83^{\mathrm{b}}$ & $7.66^{\mathrm{ab}}$ & $7.83^{\mathrm{ab}}$ \\
\hline & OS & $3.12^{\mathrm{b}}$ & $3.33^{\mathrm{fg}}$ & $7.00^{\mathrm{cd}}$ & $3.66^{\mathrm{fg}}$ & $3.12^{\mathrm{f}}$ & $7.50^{\mathrm{bcd}}$ & $6.66^{\mathrm{de}}$ & $7.00^{\mathrm{cd}}$ \\
\hline \multirow{2}{*}{ Dessu } & $\mathrm{LH}$ & $3.50^{\mathrm{ab}}$ & $3.66^{\text {cdef }}$ & $7.50^{\text {bcd }}$ & $4.12^{\text {abcde }}$ & $4.33^{\mathrm{a}}$ & $7.83^{\mathrm{b}}$ & $6.33^{\mathrm{e}}$ & $7.33^{\mathrm{bcd}}$ \\
\hline & OS & $3.12^{\mathrm{b}}$ & $3.80^{\text {bcde }}$ & $7.83^{\mathrm{ab}}$ & $3.66^{\mathrm{fg}}$ & $3.67^{\text {cde }}$ & $7.16^{\mathrm{de}}$ & $6.83^{\text {cde }}$ & $7.83^{\mathrm{ab}}$ \\
\hline \multirow{2}{*}{744} & LH & $3.66^{\mathrm{ab}}$ & $3.83^{\text {bcd }}$ & $7.12^{\text {bcd }}$ & $4.12^{\text {abcde }}$ & $4.17^{\mathrm{ab}}$ & $7.66^{\mathrm{bc}}$ & $7.33^{\mathrm{abcd}}$ & $7.16^{\mathrm{bcd}}$ \\
\hline & OS & $3.33^{\mathrm{ab}}$ & $3.66^{\text {cdef }}$ & $7.66^{\mathrm{abc}}$ & $3.50^{\mathrm{fg}}$ & $3.50^{\mathrm{def}}$ & $7.16^{\mathrm{de}}$ & $6.66^{\mathrm{de}}$ & $7.66^{\mathrm{abc}}$ \\
\hline \multirow{2}{*}{74148} & LH & $3.50^{\mathrm{ab}}$ & $3.83^{\text {bcde }}$ & $8.33^{\mathrm{a}}$ & $4.50^{\mathrm{a}}$ & $4.33^{\mathrm{a}}$ & $8.50^{\mathrm{a}}$ & $7.66^{\mathrm{ab}}$ & $8.33^{\mathrm{a}}$ \\
\hline & OS & $3.83^{\mathrm{a}}$ & $3.30^{\mathrm{fg}}$ & $7.33^{\text {bcd }}$ & $3.66^{\mathrm{bgg}}$ & $3.17^{f}$ & $7.00^{\mathrm{e}}$ & $7.16^{\text {abcd }}$ & $7.16^{\mathrm{bcd}}$ \\
\hline \multirow{2}{*}{7440} & LH & $3.50^{\mathrm{ab}}$ & $3.66^{\text {cdef }}$ & $7.83^{\mathrm{ab}}$ & $4.12^{\mathrm{ab}}$ & $4.17^{\mathrm{a}}$ & $7.66^{\mathrm{bc}}$ & $7.83^{\mathrm{a}}$ & $7.50^{\mathrm{bcd}}$ \\
\hline & OS & $3.66^{\mathrm{ab}}$ & $3.67^{\text {cdef }}$ & $7.12^{\text {bcd }}$ & $3.33^{\mathrm{g}}$ & $3.33^{\mathrm{ef}}$ & $7.66^{\mathrm{bc}}$ & $6.83^{\text {cde }}$ & $7.16^{\mathrm{bcd}}$ \\
\hline \multirow{2}{*}{ Gesha } & LH & $3.66^{\mathrm{ab}}$ & $3.67^{\text {cdef }}$ & $7.12^{\text {bcd }}$ & $4.12^{\text {abcde }}$ & $4.00^{\mathrm{abc}}$ & $7.33^{\text {cde }}$ & $7.16^{\mathrm{abcd}}$ & $7.00^{\mathrm{cd}}$ \\
\hline & OS & $3.33^{\mathrm{ab}}$ & $3.12^{\mathrm{g}}$ & $7.83^{\mathrm{ab}}$ & $3.66^{\mathrm{bcfg}}$ & $4.17^{\mathrm{ab}}$ & $7.33^{\text {cde }}$ & $7.66^{\mathrm{ab}}$ & $7.66^{\mathrm{abc}}$ \\
\hline \multirow{2}{*}{ CJ-19 } & LH & $3.83^{\mathrm{a}}$ & $4.00^{\mathrm{bc}}$ & $7.00^{\mathrm{cd}}$ & $3.83^{\text {bcdef }}$ & $3.33^{\mathrm{ef}}$ & $7.83^{b}$ & $7.00^{\text {bcd }}$ & $7.00^{\mathrm{cd}}$ \\
\hline & OS & $3.83^{\mathrm{a}}$ & $3.33^{\mathrm{dfg}}$ & $6.83^{d}$ & $3.83^{\text {bcdef }}$ & $3.33^{\mathrm{ef}}$ & $7.16^{\mathrm{de}}$ & $6.83^{\text {cde }}$ & $6.83^{\mathrm{d}}$ \\
\hline \multirow{2}{*}{ Wushwush } & LH & $3.66^{\mathrm{ab}}$ & $3.67^{\text {cdef }}$ & $7.33^{\text {bcd }}$ & $4.12^{\mathrm{abc}}$ & $4.17^{\mathrm{ab}}$ & $7.16^{\mathrm{de}}$ & $7.66^{\mathrm{ab}}$ & $7.16^{\mathrm{bcd}}$ \\
\hline & OS & $3.50^{\mathrm{ab}}$ & $3.30^{\mathrm{fg}}$ & $7.50^{\text {bcd }}$ & $4.12^{\mathrm{abcd}}$ & $3.17^{\mathrm{f}}$ & $7.16^{\mathrm{de}}$ & $7.16^{\text {abcd }}$ & $7.33^{\mathrm{bcd}}$ \\
\hline \multirow[b]{2}{*}{ Merdacheriko } & LH & $3.20^{\mathrm{b}}$ & $3.67^{\text {cdef }}$ & $7.12^{\text {bcd }}$ & $4.33^{\mathrm{e}}$ & $3.67^{\text {cde }}$ & $7.83^{\mathrm{b}}$ & $6.66^{\mathrm{de}}$ & $7.16^{\mathrm{bcd}}$ \\
\hline & OS & $3.58^{\mathrm{ab}}$ & $4.50^{\mathrm{a}}$ & $7.50^{\text {bcd }}$ & $3.67^{\text {bcdfg }}$ & $3.50^{\mathrm{def}}$ & $7.16^{\mathrm{de}}$ & $7.50^{\mathrm{abc}}$ & $7.50^{\mathrm{bcd}}$ \\
\hline CV (\%) & & 9.8 & 7.3 & 5.3 & 6.9 & 7 & 3.8 & 5.3 & 5.6 \\
\hline LSD (0.05) & & 0.57 & 0.45 & 0.65 & 0.45 & 0.43 & 0.47 & 0.62 & 0.68 \\
\hline
\end{tabular}

Means having the same letter in columns are not significant difference $(\mathrm{P} \geq 0.05)$. $\mathrm{DM}=$ drying method; $\mathrm{LH}=\mathrm{lath}$ house; $\mathrm{OS}=\mathrm{open}$ sun; $\mathrm{AI}=$ aromatic intensity; $\mathrm{AQ}=$ aromatic quality; $\mathrm{AC}=$ acidity; $\mathrm{AS}=$ astringency; $\mathrm{BI}=$ bitterness; $\mathrm{BO}=$ body; $\mathrm{FL}=$ flavor; $\mathrm{OL}=$ over all; $\mathrm{CV}=\mathrm{coefficient}$ of variation; $\mathrm{LSD}=$ least significance difference.

\section{Summary, Conclusions and Recommendations}

\subsection{Summary}

Cultivars exhibited significant differences $(\mathrm{P} \leq 0.05)$ on cup quality such as aroma, acidity, bitterness, body and flavor but not on attributes such as aromatic intensity, astringency and overall quality.

Drying method showed significant $(\mathrm{P} \leq 0.05)$ differences on aromatic quality, astringency, bitterness and body. Similarly, the interactions of cultivars and drying methods also showed significant difference $(\mathrm{P} \leq 0.05)$ on most cup quality attributes such as aromatic quality, astringency, acidity, bitterness, body, flavor and overall quality except aromatic intensity attribute. The cup qualities of coffee such as body, flavor, overall, astringency and bitterness were better for beans dried under lath house as compared to those subjected to open sun drying.

\subsection{Conclusions}

The highest value in most cup quality attributes were record for cultivars Gesha and 74148. Similarly, cultivars of 744 and 7440 were also high in all cup quality parameters.
Net lath house drying method was better in all cup quality attributes. The effect of drying method was significant $(\mathrm{P} \geq 0.05)$ difference on cup coffee quality parameters such as aromatic quality, astringency, bitterness, body and flavor.

\subsection{Recommendations}

Further studies should be under taken in the area of coffee bean drying methods to maintain and improve the quality of the bean obtained after harvesting including major chemical composition of beans.

To avoid cracking and physical damage to the beans by overheating other drying method like net lath house drying is recommended rather than direct open sun drying. It is also important to prevent dust and dirt blown to drying parchments and to reduce labor cost.

\section{Acknowledgements}

We acknowledged the Ethiopian Institute of Agricultural Research (EIAR) for supporting the finance and certified professional cuppers of Jimma Agricultural Research Centre (JARC) for evaluating the prepared samples. We also extent our collogues of coffee processing and quality staff including Teppi research center and Gera sub center staff for assisting in coffee sample preparation. 


\section{References}

[1] Abrar S., Solomon E., and Ali M., 2014. Processing method, variety and roasting effect on cup quality of arabica Coffee (Coffea arabica L.); Discourse Journal of Agriculture and Food Sciences, 2 (2): 70-75.

[2] Abrar S. and Negussie M., 2015. Manual for Coffee Quality Laboratory ISBN: 978999446605410-8.

[3] Agwanda, C. O., Baradat, P., Eskes, A. B., Cilas, C. and Charrier, A. 2003. Selection for bean and liquor qualities within related hybrids of Arabica coffee inmulti local field trials. Euphytica, 131, pp. 1-14.

[4] Agwanda, C. O. 1999. Flavor is ideal selection criterion for the genetic improvement of liquor quality in Arabica coffee. pp. 383389, In: the proceedings of $18^{\text {th }}$ International Scientific Colloquiumon Coffee, Helsinki, Finland.

[5] Anthony, F. Bertrand, B., Quiros, O., Lashermes, P., Berthaud, J. and Charrier, A. 2001. Genetic diversity of wild coffee (Coffeaarabica L.) using molecular markers. Euphytica 118: 53-65.

[6] Anwar A., 2010. Assessment of coffee quality and its related problems in Jimma zone of Oromia regional state abdiga. MScthesis submitted to Jimma University.

[7] Beer, J., Muschler, R., Kass, D. and Somarriba, E. 1998. Shade management in coffee and cacao plantations. Agroforestry Systems 38: 139-164.

[8] Behailu W., and Solomon E., 2006. The influence of shade during fermentation stage of wet processing on the cup quality of Arabica coffee, $21^{\text {st }}$ International Scientific Conference on Coffee Science (ASIC). September 2006, Montpellier, France, pp. 549-553.

[9] Behailu W., Abrar S., Nugussie M., and Solomon E., 2008. Coffee processing and quality research in Ethiopia. In: Proceedings of a national work shop four decades of coffee research and development in Ethiopia, EIAR, Addis Ababa, Ethiopia. pp. 307-316.

[10] Boot. 2006. Reported that improper drying practices are the root cause of many flavor taints in coffee.

[11] Clifford, M. N. 1985. Chemical and physical aspects of green coffee and coffee products. In: Clifford, M. N. and Willson, K. C. (eds.), Coffee botany, biochemistry, and production of beans and beverage, Croom Helm, London. pp. 305-374.

[12] CLU (Coffee Liquoring Unit). 2007. Training manual for trainee coffee cuppers, coffee quality inspection and auction center, Addis Ababa Ethiopia, June, 2 007. pp. 4-6.

[13] Correa, P. C., Resende, D. M. and Ribeiro. 2006. Drying characteristics and kinetics of coffee berry. Revista Brasil eira De Produtos Agro industriais, Campina Grande, 8 (1): 1-10.

[14] Davis, A. P., Govaerts, R., Bridson, D. M. and Stoffelen, P., 2006. Anannotated taxonomic conspectus of the genus Coffea (Rubiaceae). Botanical Journal of the Linnaean Society, 152 (4), pp. 4 65-512.

[15] Endale A., 2008. Physical quality standards and grading systems of Ethiopian coffee indemand and supply chain. In: Proceedings of anational workshop our decades of coffee research and development in Ethiopia, EIAR, Addis Ababa, Ethiopia. pp. 328-334.

[16] FAO (Food and Agriculture Organization) 2010. Introduction to coffee drying. 'Good Hygiene Practices in the Primary Production of Coffee. Retrieved from: Http://Www.Zecuppa.Com/ Coffee terms bean grading. (Accessed on October 5, 2018).

[17] Franca, A. S., Oliveir, L. S. Mendonça, J. C. and Silva, X. A. 2005. Physical and chemical attributes of defective crude and roasted coffee beans. Journal of Food Chemistry, 90 (1-2), pp. 89-94.

[18] Getachew E., Berhanu T., Ali M., Tesfaye S., and Yehenew G.., 2015. Influence of sun drying methods and layer thickness on quality of middle and arabica coffee varieties at Gomma II, South West Ethiopia. Global Journal of Agricultural Science. 3 (2): 203-212.

[19] Giomo, G., Borem, F., Saath, R., Mistro, J., Figueiredo, L., Ribeiro, F., Pereira, S. and Bernardi, M. 2012. Evaluation of green bean physical characteristics and beverage quality of arabica coffee varieties in Brazil. In: $24^{\text {th }}$ International Conference on Coffee Science 12 th $-16^{\text {th }}$ November.

[20] Girma, M. 2003. Agrometrology geographic information system to enhance coffee. Impact of specialty coffee increased quality and profits for smallholders. California, Colombia.

[21] Girma H., Digafie T., and Edossa E., 2009a. Spices research achievements, revised edition, Ethiopian Institute of Agricultural Research, Addis Ababa Ethiopia, 34-42.

[22] Hicks, A. 2002. Post Harvest Processing and Quality Assurance for Specialty/Organic Coffee http://tw.myblog.yahoo.com/jw!gGk._TCGBxzkQso4M2w/Ht tp://Www.Fao.Org/Docrep/003/X6939E/X6939e03.Htm (Accessed On: 08-07-2010).

[23] ICO (International Coffee Organization). 2010. V (3): 10.

[24] ISO. 2000. International Standard ISO 9000: Quality management systems fundamentals and vocabulary.

[25] Lashermes, P., Combes, M. C., Robert, J., Trouslot, P., Hont, A. D., Anthony, F. and Charrier, A. 1999. Molecular characterization and origin of the Coffea Arabica L. Genome. Molecular Genetics. 261: 259-66.

[26] Lower, S. T., Amoah, F. M. and Opaku Amoyowo. K. 2007. Drying Process and Ghanaian Green Coffee quality crude protein, caffeine levels. Cacoa Research Institute of Ghana, pp: 698-699.

[27] Mayne., Tola, A. and Kebede, G. 2002. Crisis in the Birth Place of Coffee: The coffee crisis in the Kaffa province of Ethiopia. Oxfam International Research Papers.

[28] Muschler, R. G. 2001. Shade improves coffee quality in asub optimal coffee zone of Costa Rica, agro forestry systems, pp. 131-139.

[29] Mutua, J. 2000. Post harvest handling and processing of green Coffee in African countries.

[30] Pearl, H. M., Nagai, C., Moore, P. H., Steiger, D. L., Osgood, R. V. and Ming, R. 2004. Construction of agenetic map for Arabica Coffee products. Paper Presented at FAO regional office for Asia and the Pacific, Bangkok, and theory. Applied Genetics. 108: 829-835. 
[31] QSAE (Quality and Standards Authority of Ethiopia). 2000. Training manual on introduction to ISO 9000: Quality management system, QSAE, Addis Ababa, Ethiopia.

[32] Reh, C. T., Gerber, A., Prodoillet, J. and Vuataz, G. 2006. Watercontent determination in green coffee method comparison to study specificity and accuracy. Journal of Food Chemistry. 96: 423-430.

[33] Selmar, D. Knopp, S. and Bytof, G. 2006. Influence of processing on the content of sugars in green Arabica coffee beans. European Food Research and Technology, 223 (2), p. 195.

[34] Shamil, A., Abebe, G. and Wakjira, G. 2017. Study on Performance Evaluation of Tomato (Lycopersiconesculentum Mill.) Varieties under offseason Conditionat Teppi, South Western Part of Ethiopia. Greener Journal of Agricultural Sciences, 7 (5): 120-125.

[35] Sharma, A., Chen, C. R. and Lan, N. V. 2009. Solar drying systems: A review. Renewable and sustainable energy reviews, 13 (6-7), 1185-1210.

[36] Sivetz, M. and Foote, H. E. 2004. Coffee processing
Technology. The AVI Publishing Company, Incorporated. West port, Connecticut, U.S.A.

[37] Subedi, R. N. 2011. Comparative analysis of dry and wet processing of coffee with respect to Quality in Kaure District, Nepal: Acase of Panchkhal Village. International Research Journal of Applied and Basic Sciences, 2 (5): 181-19.

[38] Taye K., 2013. Status of Arabica coffee Germplasmin Ethiopia center director and Senior Coffee Researcher EIAR / Jimma Research Center.

[39] Taye K., Ashenafi A., Alemseged Y., Teshome K., and Wondiyfraw T. 2011. The contribution of coffee research for coffee seed development in Ethiopia, Journal of Agricultural Research Development, 1 (1): 009-016.

[40] Wanyonyi, J. J. M. 1999. An out line of coffee processing. Crop production division, Ministry of Agriculture, Nairobi, Kenya.

[41] Yigzaw D. 2006. Assessment of genetic diversity of Ethiopian Arabica coffee genotypes using morphological, bioche micaland molecular markers. $\mathrm{PhD}$ dissertation, University of the Free State, Bloemfontein, South Africa. 